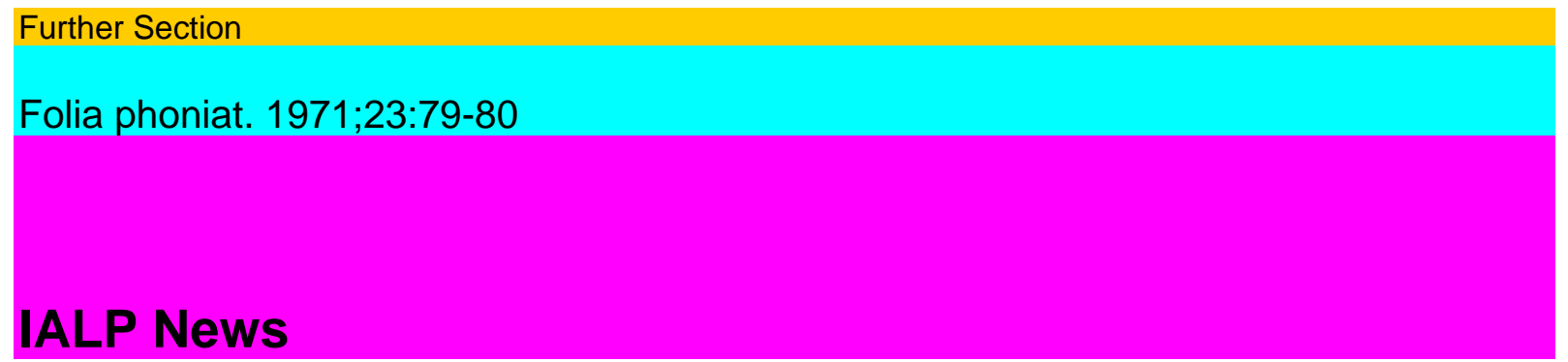

Consultative status with WHO, UNESCO and UNICEF

Affiliated Associations

For the Secretaries of the Affiliated National Associations

The General Secretary of IALP requests the secretaries of the National Associations to indicate the names of the proposed national delegates before June 1, 1971. Not more than two delegates for each country will be accepted (By-laws art. 7, sec. 2). The nominated delegates for the International Congress in Buenos Aires will not be accepted until they have shown their letter of presentation to the General Secretary.

The General Secretary will consider suggestions for candidates to be nominated to the new Board in Buenos Aires. All individual members are entitled to propose names for the new Board. Only individual members of IALP can be elected for the Board. The General Secretary should be in possession of the suggestions including written acceptance by the nominated persons before June 1, 1971.

80

\title{
IALP News
}

The Assembly of delegates will take place in Buenos Aires during the Congress. The delegates are entitled to make comments on the activities of IALP and to propose new activities during the Assembly.

In August, during the Congress of IALP, the General Assembly will take place. One of the most important subjects to be discussed is the modification of the statutes. The Board requires the assistance of all individual members and delegates of the affiliated associations.

Awards

The William and Harriet Gould Foundation announces the recipient of the 1970 Gould A.ward : Dr. Nobuhiko Isshiki of Kyoto, Japan.

Dr. Isshiki was honored for his aerodynamic research of laryngeal physiology.

Congresses

Speech Symposium

The Hungarian Association of Phonetics, Phoniatrics and Logopedics, the Research Institute of Linguistics of the Hungarian Academy of Sciences and the Training College for Teachers of Handicapped Children organise an Speech Symposium from 26 to 29 August 1971.

Secretary Mrs. Emöke Kovács, Gyógypedagógiai, Tanárképzo Föiskola, Budapest VII

(Hungary).

Deutsche Gesellschaft für Sprach- und Stimmheilkunde

Die Jahresversammlung 1971 wird am 22. Mai 1971 im Hotel Elite, Zenostrasse 9, Bad

Reichenhall stattfinden. Vortragsanmeldungen bitte an den Geschäftsführer Prof. E. Loebell, Inselspital, CH-3000 Bern (Schweiz).

Courses

March 30 to April 2, 1971 
Midland Area Refresher Course in Leicester, England. Speakers: T. Bill, J. Cooke, M. Greene, M. Edwards, H. Kinmonth, J. Perello and N. Pyper.

Information: Miss E. G. Barlow, Dept. of Speech Therapy, College of Education, Scraptoft, Leicester, LE 79 SU (England).

Linguistic Institute July 5 to August 27, 1971

Course on Focus for intellectual integration in Buffalo.

Information: Linguistic Institute, 324 Hayes Hall, State University of New York at Buffalo, Buffalo, New York 14214 (USA). 